\title{
INFLUENCE OF EXTREME DISCHARGE ON RESTORATION WORKS IN MOUNTAIN RIVER - A CASE STUDY OF THE KRZCZONÓWKA RIVER (SOUTHERN POLAND)
}

\author{
Anna Lenar-Matyas' ${ }^{1}$, Joanna Korpak' ${ }^{1}$ Andrzej Mączałowski ${ }^{1}$ \\ 1 Cracow University of Technology, Warszawska 24, 30-155 Kraków, Poland, e-mail: alenar@iigw.pl; jkorpak@ \\ iigw.pl; andrzej.maczalowski@iigw.pl
}

Received: 2015.03.18

Accepted: 2015.06.02

Published: 2015.07.01

\begin{abstract}
The research was conducted on the Krzczonówka River channel, one of the gravelbedded, regulated mountain river in Polish Carpathians. The main morphological and ecological problem of the river was lack of sediment and channel downcutting. The area is currently associated with an on-going project called "the Upper Raba River Spawning Grounds”. Lowering of an existing debris dam on Krzczonówka River is a part of the project. In 2013 twelve artificial riffles have been created by heaping up stones at points within the segment of the river channel below the debris dam. The riffles are to introduce variety to the longitudinal profile of the river and to reduce the river's slope. Consequently, these are to decrease sediment transport and to prevent further deepening of the river channel. Post-project monitoring of river restoration works is conducted to determine channel changes and development. In May, 2014, extreme flooding occurred, which caused unexpected changes in channel development. This paper describes maintenance work performed in the riverbed of the Krzczonówka River. Observations and calculations concerning changes in conditions of water flow and sediment transport are also presented. The main purpose is to characterize the influence of an extreme flow event on morphology and functioning of the recently restored gravel-bed river.
\end{abstract}

Keywords: mountain river maintenance, river channel processes, artificial riffle, debris dam reconstruction.

\section{INTRODUCTION}

Most rivers in the Polish Carpathians have been regulated in the last decades, the continuity of the fluvial systems has been interrapted. Ecological state of these rivers is very poor. The EU Water Framework Directive (WFD) requires member states to improve river water quality. Thus, on some Carpathian rivers, the restoration projects are curried out [Wyżga et al. 2012]. One of these rivers is the Krzczonówka River - left tributary of the Raba River.

The Krzczonówka River has been regulated many times since the early $20^{\text {th }}$ century. Its channel was straightened, narrowed and horizontally shifted . The detailed investigation was focussed on the fully trained lower course of the channel from the debris dam at river kilometer $2+440$ to the mouth. The stream segment is a part of Nature 2000 area - an ecological network of protected areas, set up by the European Union to ensure the survival of Europe's most valuable species and habitats. The studied reach is a natural area inhabited by valuable fish species. The fish that inhabit this part of the river typically require natural, gravel streambeds to be part of their habitat. This ensures their proper development.

However, the existing dam breaks the natural continuity of the fluvial system. It makes fish migration difficult. It also limits sediment transport from the upper part of the stream. This causes stream bed erosion and significantly reduces sediment load [Korpak et al. 2008]. 
The implementation of "The Upper Raba River Spawning Grounds" restoration project began in 2012. Its aim is to restore the natural, alluvial channel of the Raba River as well as its tributaries. Another goal is to restore and protect the floodplain in terms of water retention capability of the river channel and protective plant cover. The geographic area for the project implementation is the Raba River valley between the towns of Lubien and Stróża and the lower parts of two tributaries: Krzczonówka and Trzebuńka Rivers. The entire project is an innovative one in Poland [Ab ovo 2011].

The changes in channel morphology and hydraulic conditions after restoration works have been monitored since 2013. In May, 2014, extreme flooding occurred, which caused additional, unexpected changes in channel development. The transformations of the stream reach were significant enough to be able to present first results of measurements and to draw initial conclusions concerning new conditions of water flow and sediment transport. The main purpose of this paper is to characterize an influence of an extreme flow event on morphology and functioning of the recently restored gravel-bed river. The effectiveness and durability of the proposed restoration solutions in the mountain rivers are also considered.

\section{MATERIALS AND METHODS}

The area that "the Upper Raba River Spawning Grounds" Project is focused on is monitored by the authors of this work on a continuous basis. These observations and research activities include geodetic measurements, and geomorphologic mapping. The assumed research cycle is one year long, which might be repeated in the case of a subsequent occurrence of extreme phenomena.

The geodetic measurements are performed using a Topcon HiPer II GPS receiver set. These include cross section measurements and water level measurements. Comparative analysis of shapes and sizes of cross sections allow determining the trends in channel morphometry changes and their influence on the conditions and capacity of water flow.

Geomorphological mapping is performed using the "River channel mapping instructions" [Kamykowska et al. 1999]. All fluvial features are identified and measured in the field. Furthermore, current trends in the morphodynamic processes in different segments of the stream channel are being evaluated.

Historical changes in the stream channel course and geometric parameters of the researched reach of the Krzczonówka River were also analyzed. The changes in the course and dimensions of the river channel that occurred in the last 50 years were re-created and measured based on the analysis of rectified aerial photographs taken in 1963 and in 1977 and of orthophotomaps dating back to 1997 and 2006.

\section{STUDY REACH CHARACTERISTICS}

Krzczonówka River is a small left-bank tributary of the Raba River. It is $16.7 \mathrm{~km}$ in length. Its spring is found at an elevation of $740 \mathrm{~m}$ asl. The Krzczonówka River valley lies in the West Carpathians (Southern Poland) and separates the mountain range of Beskid Wyspowy from the mountain range of Beskid Makowski. Beskid Wyspowy and Beskid Makowski Ranges are built of sedimentary rocks, mainly sandstone, shale and marl. The catchment area is $87.6 \mathrm{~km}^{2}$. The area is mountainous, the elevations range from $329 \mathrm{~m}$ asl at the mouth to $866 \mathrm{~m}$ asl at the highest point. (Figure 1) The average annual precipitation is about $800 \mathrm{~mm}$. Floods typically occur during summer rainfall. River discharge varies greatly; the minimum discharge for the 1966-1990 period was 0.1 $\mathrm{m}^{3} \mathrm{~s}^{-1}$ whereas the maximum was $170 \mathrm{~m}^{3} \mathrm{~s}^{-1}$. The average annual discharge for the 1971-1990 period was $1.62 \mathrm{~m}^{3} \mathrm{~s}^{-1}$ (data from Institute of Meteorology and Water Management).

The researched stream segment $(2,440 \mathrm{~m}$ in length) with the surrounding wide valley comprise a protected area and are a part of the Nature 2000 system. The terrain adjacent to the stream banks is forested. A riparian forest and an oakhornbeam forest are two types of forest present in this area. These are important habitats for many species of plants and animals as well as play a significant role in the dispersal of species.

\section{PAST CHANGES IN THE SHAPE OF THE STREAM CHANNEL}

The researched stream channel segment begins at an old debris dam. The construction of the dam was begun in 1935, and it was completed in 1951. Many longitudinal hydraulic structures that direct the flow, and embankments were built 


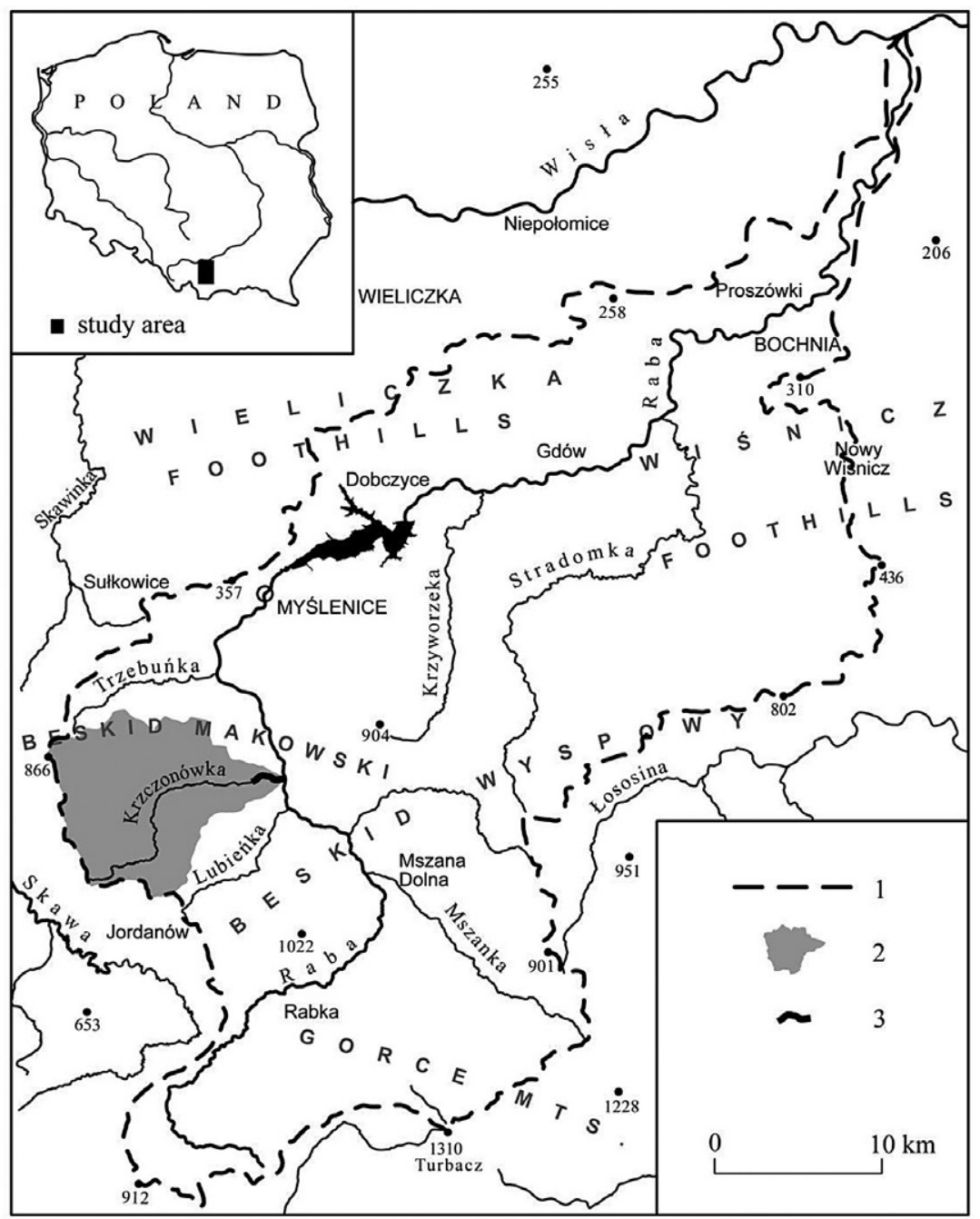

Figure 1. Study area: 1 - the Raba River catchment, 2 - the Krzczonówka River catchment, 3 - the studied reach of the Krzczonówka River

downstream of the debris dam in different years to regulate the flow. Many of the structures were built in the late 1950s and early 1960s. The transverse structures that are seen on the aerial photograph taken in 1963, had been constructed recently before the photo was taken, as the areas between them are covered with soil, but not yet covered with vegetation (Figure 2).

The role of the hydraulic structures was to concentrate the flow and to divert it from both banks. This way a narrower channel was formed in order to protect the roads that run along the stream banks from the consequences of lateral erosion. More hydraulic structures were built in subsequent years. Information on this issue is found in the register of regulation works performed in the Krzczonówka River, obtained from Cracow's Regional Water Management Authority. The register is fairly incomplete. However, it does contain information on construction of other river regulation structures. These include a longitudinal dam built in 1992 at river kilometer 0.26-0.52, which was constructed of stone, and channel segment regulation performed in 1999 at river kilometer $0.40-1.25$ in the form of embankments made of rock armour.

The stream channel of the Krzczonówka River, downstream of the debris dam, was straightened and became much more narrow as a result of the regulation works performed in it (Figure 3 ).

A representation of measurement data on the active channel width of the Krzczonówka River is shown in Figure 4. The active channel was defined as a low-flow channel with unvegetated bars. The measurements made from photograph taken in 1963 cover the channel width from before construction of the longitudinal structures.

The average width decreased over time by the factor of more than three: from $46 \mathrm{~m}$ before 1963 , down to $29 \mathrm{~m}$ in 1997, and down to $15 \mathrm{~m}$ in 2006. 


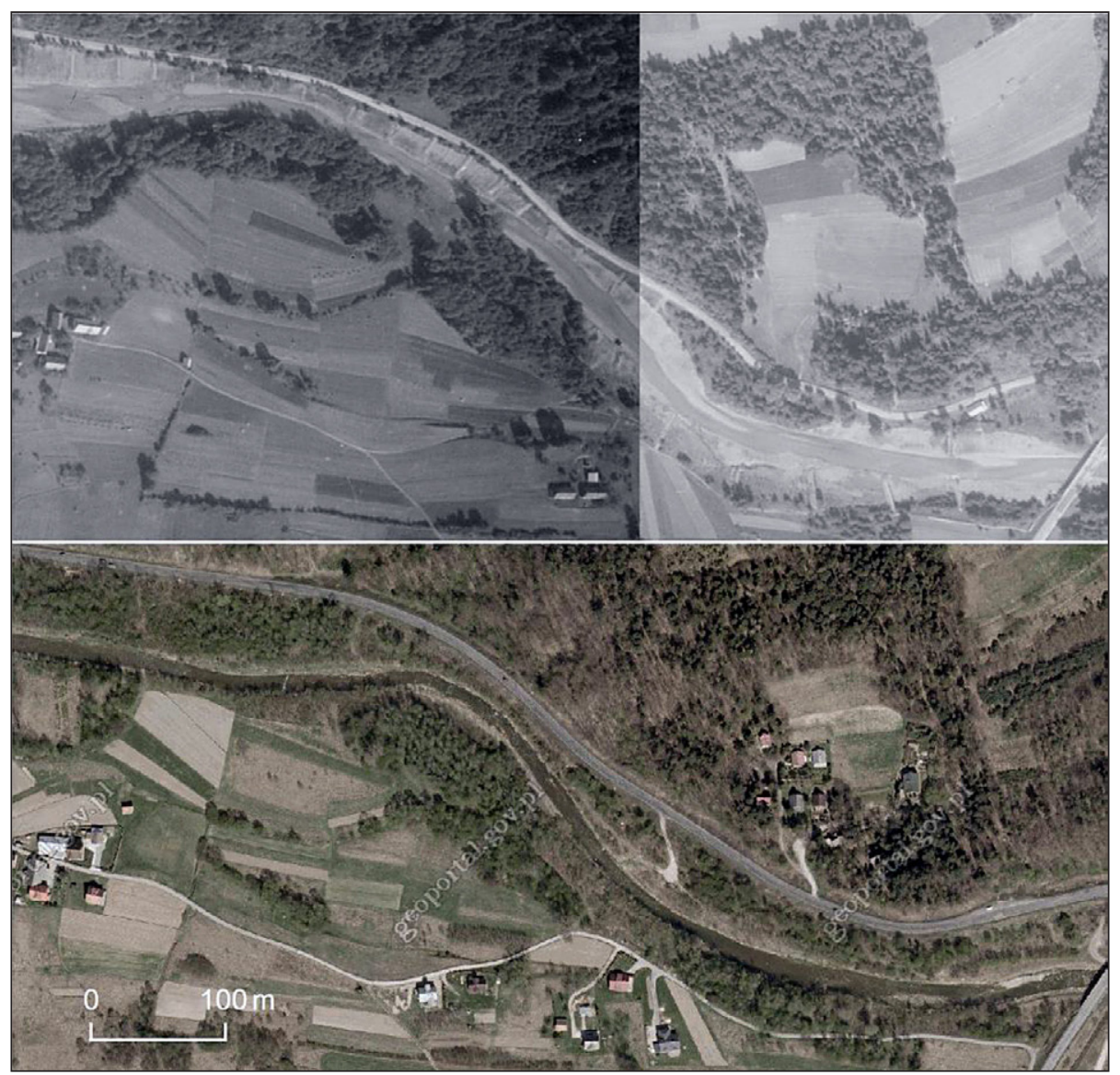

Figure 2. Aerial photos of the lower reach of the Krzczonówka River in 1963 (above) and 2006 (below)

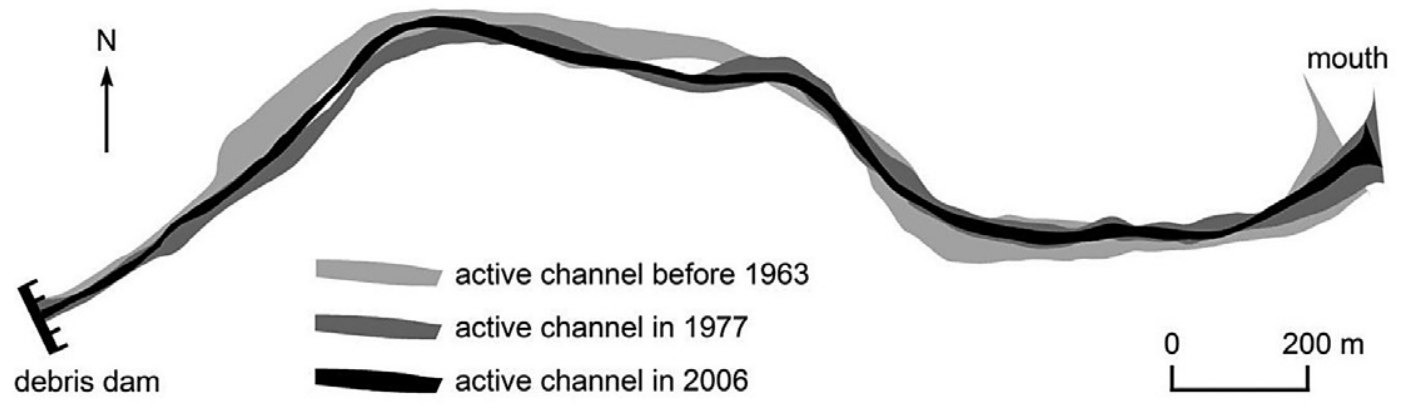

Figure 3. Changes in the course of the channel of the Krzczonówka River in its lower reach

The channel width became more uniform over the longitudinal profile. The average area of the stream channel and the floodplain that is covered with water during high water stages, decreased from about $102000 \mathrm{~m}^{2}$ before 1963 down to about $32000 \mathrm{~m}^{2}$ in 2006. Such sizeable changes in stream channel capacity caused strong vertical erosion and deepening of the channel. The channel downcutting was additionally caused by the shortage of bedload. The material, transported from the upstream reaches of the stream channel, was being trapped in the reservoir above the existing debris dam. At the same time, the supply of sediment that originated from the stream banks, was limited due to the construction of embankments and longitudinal dam structures. As a result of strong downward erosion, the studied reach of the stream channel was characterized in 2006 by long segments of rocky stream bed, in some places covered with a thin layer of alluvium. Every flood stage caused further deepening of the stream channel and depositing of sediment at the stream mouth. The river was characterized by a lack of hydrodynamic stability and a poor ecological status in terms of living conditions for the flora and fauna. The debris dam with a dysfunctional fish pass prevented migration of fish of the Salmonidae family to the spawning grounds. 


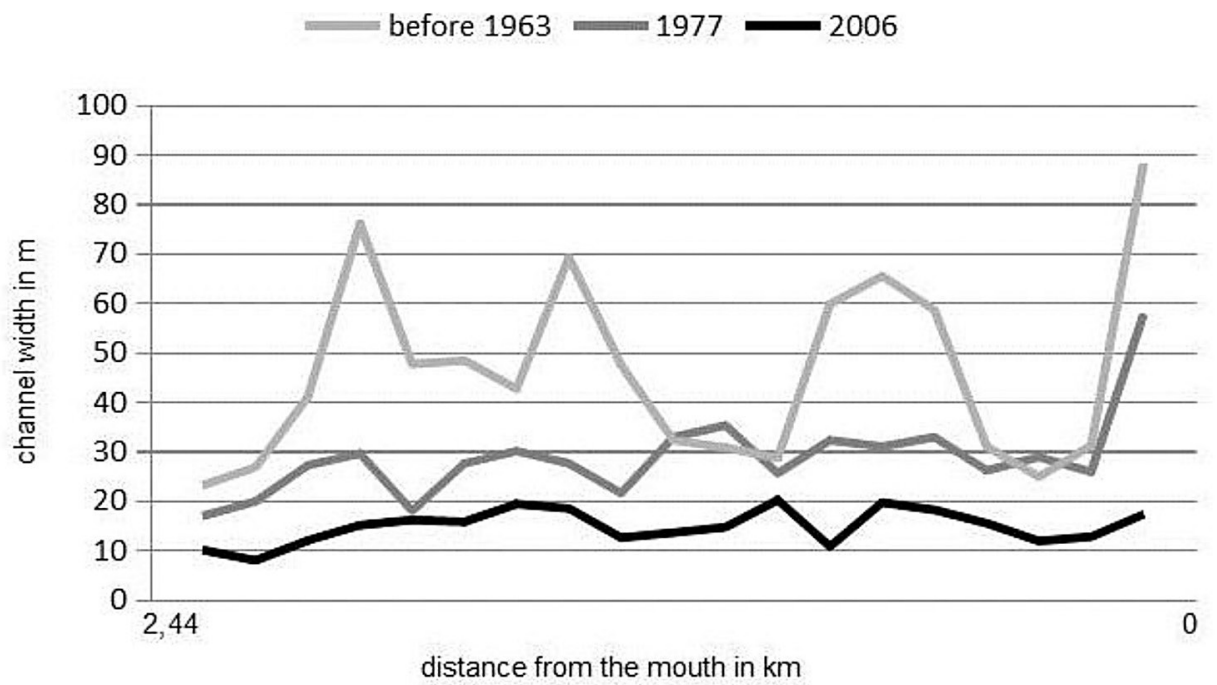

Figure 4. Changes in the width of the channel of the Krzczonówka River in its lower reach

\section{TECHNICAL INTERVENTIONS CONDUCTED AFTER 2012}

The on-going project, implemented in 2012, called "The Upper Raba River Spawning Grounds", is aimed at improving the condition of the river. The works that are planned in the Krzczonówka River channel include:

- reconstruction of the debris dam at river kilometer $2+440$ in order to remove the migration barrier and provide the possibility of opening a way for sediment transport from the reach above the dam,

- formation of riffles of stone rubble in order to maintain hydrodynamic equilibrium of the stream channel within the stream section reaching from the dam down to its mouth,

- maintaining control over sediment transport by supplying bedload

As the studied reach of the Krzczonówka River is located in a Nature 2000 area, the works under- taken should contribute to ecological restoration of biotopes and to restitution of species [Zając and Zając 2006]. At the same time, the changes that are being introduced should not impede economic development of the region and interfere with flood protection systems [Nienhuis and Leuven 2001].

Twelve riffles were constructed at the beginning of 2013 and were situated roughly every 120 meters. The sites were chosen in such a way that a riffle crest was located at one of the current's inflection points. These are the points on the thalweg, where the transition from a pool to a riffle naturally occurs (Photo 1). The constructed structures raise the crest of an existing riffle. They are made of stone rubble of variable diameter, which are not reinforced with concrete, just compacted using machinery. The core part of a riffle is composed of very large blocks of broken rock of diameter larger than one meter. The spaces between them were filled with small-grained rubble, composed of rocks of small diameter ranging from sand and gravel aggregate down to fine sand.
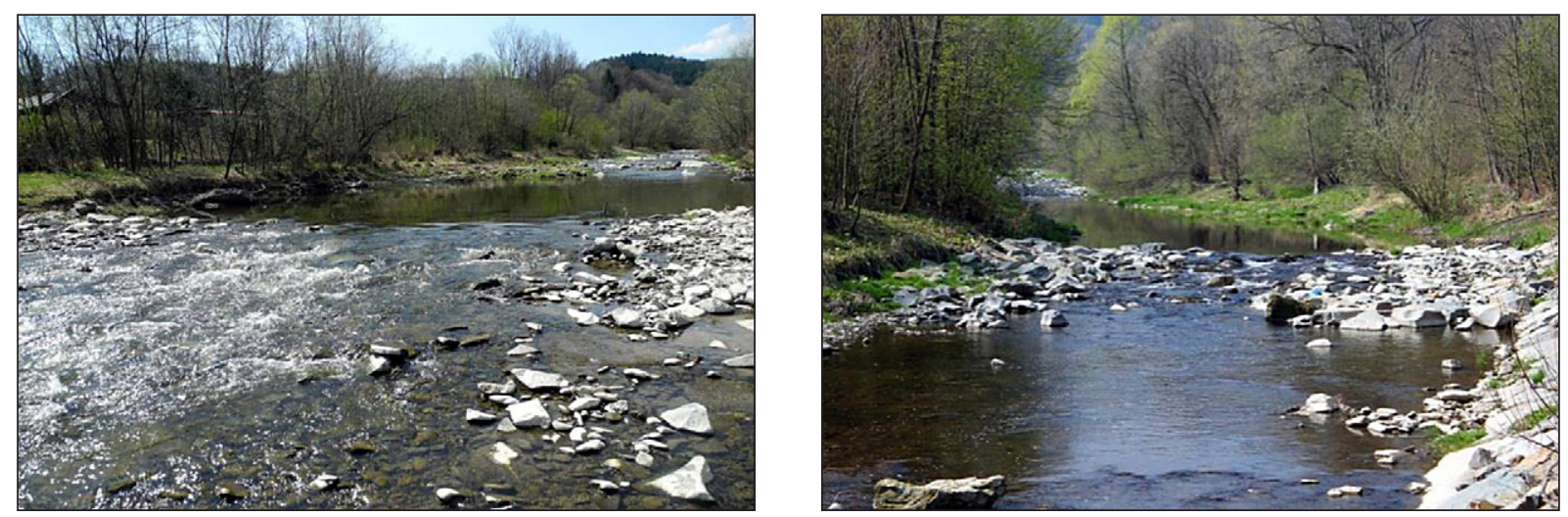

Photo 1. Sample two out of 12 riffles constructed in the Krzczonówka River 
The height of a riffle crest is different for different structures. It depends on local conditions, and ranges from 0.6 to $1.2 \mathrm{~m}$ (Figure 5). Raising the crest of natural riffles causes a decrease of unit stream power at the end of the pool as well as on the riffle crest [Bojarski et al. 2005]. This limits sediment transport, and consequently decreases erosion. Moreover, riffles are to introduce variety into the longitudinal profile of the stream and to decrease the slope of stream water surface. Similar structures were already described multiple times in terms of project planning and design [Kapitzke 2010, Mooney et al. 2007], as well as their construction [DVWK 2002, Radecki-Pawlik 2013, Rosgen 2006, Ślizowski 1993, Ślizowski and Radecki-pawlik 1999], durability [Torre 2001] and their impact on the stream channel [Darby and Sear 2008, Łapuszek and Lenar-Matyas 2013]. In the case of the researched reach of the stream the project of building the riffles is tied to the lowering of the debris dam. These are different conditions than the ones described before, and that is why they are exceptional.

Work on the modernization of the debris dam started at the beginning of April, 2014.
The dam will be lowered by about two meters. The additional construction of "pool and traverse" fish pass including pools and a series of six traverses with heights of $0.3 \mathrm{~m}$ will help fish migrate upstream.

\section{EXTREME RAINFALL AND FLOODING IN MAY OF 2014}

Heavy rains occurred in southern Poland in the middle of May, 2014. The sudden rains caused a significant increase of flow rate in rivers and streams. A high discharge event also occurred in the Krzczonówka River, according to the data recorded at the Krzczonów water gauge. The maximum discharge was about $250 \mathrm{~m}^{3} / \mathrm{s}$. It occurred overnight on May 15 into May 16. Such discharge is close to a discharge that has a likelihood of occurrence of $1 \%$, which, according to the Institute of Meteorology and Water Management, equals $270 \mathrm{~m}^{3} / \mathrm{s}$.

Rains and high discharges coincided in time with the modernization works performed on the

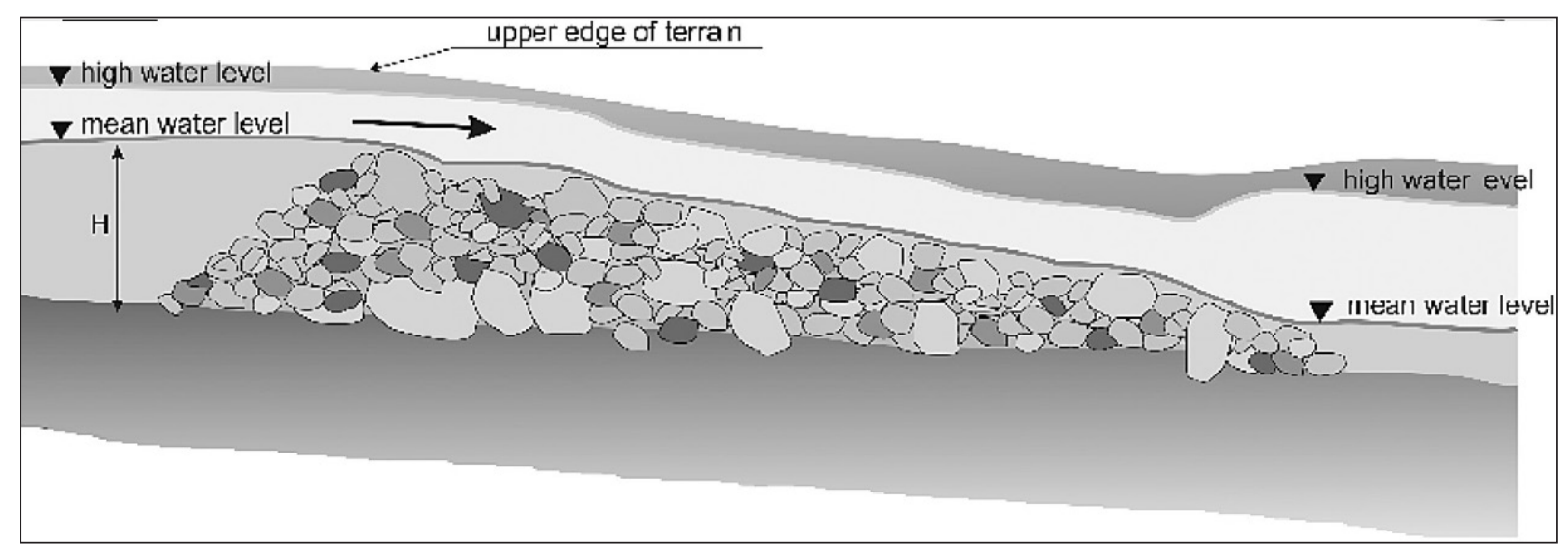

Figure 5. Sketch of a typical riffle, constructed in the Krzczonówka River - a longitudinal profile

a)

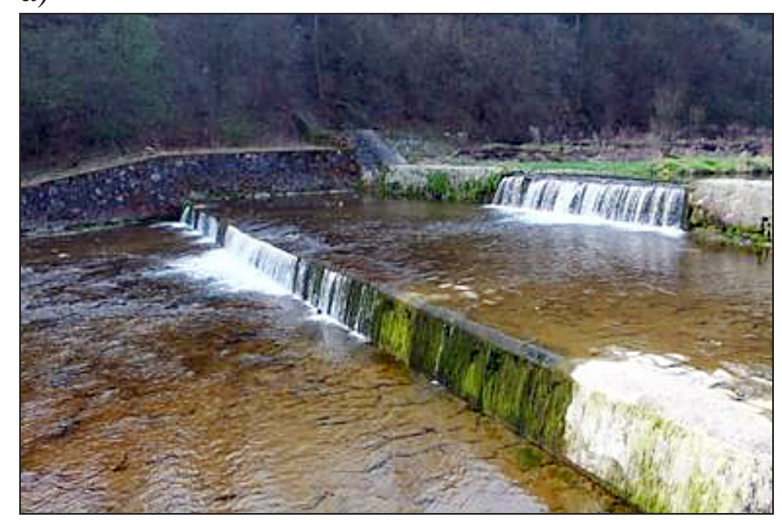

b)

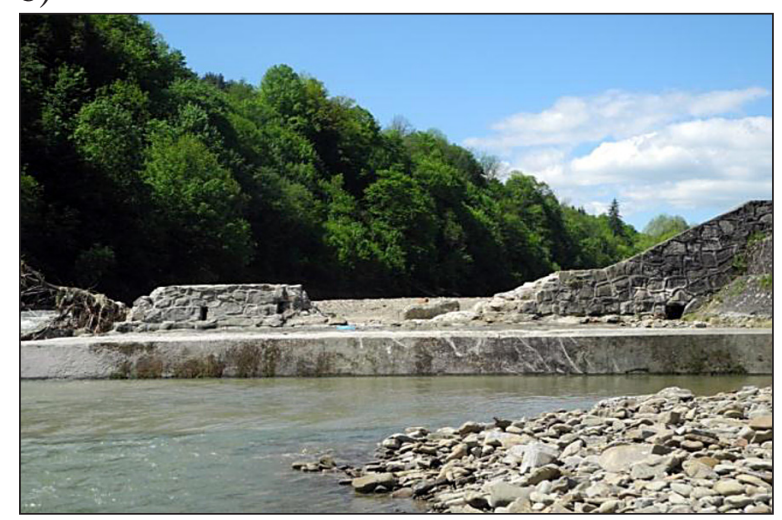

Photo 2. Debris dam on the Krzczonówka River at km $2+440$, a - the dam before modernization, $\mathrm{b}$ - the dam during modernization, after the high discharge event 
debris dam. In effect, this caused large amounts of sediment to be transported at the time. This, in turn, caused significant changes to the segment of Krzczonówka River being described.

\section{RESULTS: INITIAL OBSERVATIONS AND MEASUREMENTS}

\section{Changes in channel morphology}

Geomorphological mapping was performed in May of 2013 (a short time after riffles had been constructed) and in June of 2014 (after the May flooding). The reach of the channel downstream of the debris dam is uniform in terms of morphology. Its width is, on average, $15 \mathrm{~m}$. Concave banks at stream bends and some banks where the channel is straight are reinforced mostly with riprap or rock-filled gabions.

Small point bars were the most common morphological feature among bed forms in 2013 (Table 1). Mid-channel bars were scarce. The banks were being undercut locally at many sites, but the bank segments were short. Lateral erosion played a secondary role. The height of cutbanks exceeded $2 \mathrm{~m}$ in some places. Presence of rock steps and outcrops and large height of banks were proofs of significant deepening of the stream channel. The channel displayed a tendency to recreate a new balanced profile after the riffles had been constructed. None of the fluvial processes became dominant in terms of shaping the stream bed. Deposition of sediment in the form of bars occurred in the stretches of the stream channel located between riffles, since the stream slope decreased due to the construction of the riffles. However, the bars were small and there were only a few of them, since the supply of material being carried was limited.

The mapping performed in June of 2014 showed great changes in the shape of the studied river channel reach. First, the number of midchannel bars increased significantly (Table 1). Dimensions of point bars and mid-channel bars also increased (Figure 6). The number of cutbanks increased while the number of rock steps and outcrops decreased. Deposition is the primary process transforming the stream channel. This occurred thanks to a large supply of sediment during the flood stage in May of 2014. The volume of sediment load exceeded the river's capacity. The material supplied was delivered from the upstream reach of the stream channel, which lies above the debris dam. It took place due to the lowering of the dam. The material was also delivered from cutbanks. There were some segments of the stream channel, where the bank retreated several tens of centimeters. Some bank reinforcements were also heavily damaged. The structures of most new riffles are not noticeable. There is only a slight change in the stream slope angle, in the spots where they are found.

\section{Changes in the channel cross sections}

Geodetic measurements of the studied Krzczonówka River reach were begun in 2013 and were

Table 1. Characteristics of the Krzczonówka River channel segment stretching from its mouth up to the debris dam, as recorded during geomorphological mapping performed in 2013 and 2014

\begin{tabular}{|c|c|c|}
\hline Parameter & May 2013 & June 2014 \\
\hline Stream channel length [m] & \multicolumn{2}{|c|}{2440} \\
\hline Stream channel width $[\mathrm{m}]$ & \multicolumn{2}{|c|}{ about 15} \\
\hline Number of point bars & 15 & 15 \\
\hline Number of mid-channel bars & 4 & 11 \\
\hline Length of point bars: average (min-max) [m] & $63(15-120)$ & $87(14-180)$ \\
\hline Width of point bars: average (min-max) [m] & $6.3(1.5-15)$ & $8.5(2-15)$ \\
\hline Length of mid-channel bars: average (min-max) [m] & $33(13-80)$ & $72(7-100)$ \\
\hline Width of mid-channel bars: average (min-max) [m] & $2.4(2-2.5)$ & $8.6(1-18)$ \\
\hline Share of the area of bars in the whole stream channel area [\%] & 20 & 56 \\
\hline Number of cutbanks due to lateral erosion & 7 & 11 \\
\hline Length of cutbanks: average (min-max) [m] & $49(10-120)$ & $40(5-100)$ \\
\hline Height of cutbanks: average (min-max) [m] & $1.1(0.6-2.0)$ & $1.1(0.35-2.5)$ \\
\hline Number of rock steps and outcrops & 12 & 5 \\
\hline Most frequent height of rock steps and outcrops [m] & \multicolumn{2}{|c|}{$0.3-0.4$} \\
\hline
\end{tabular}




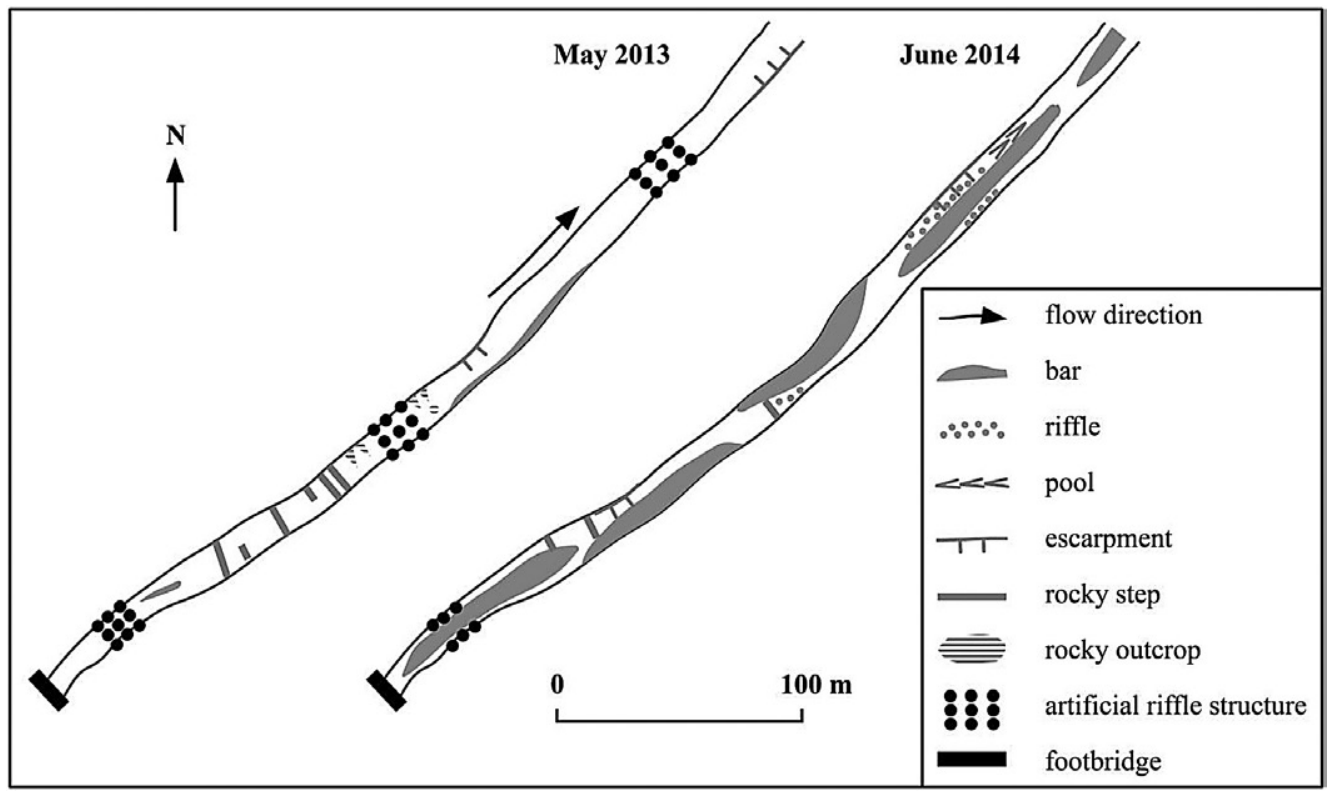

Figure 6. Plan view of the stream channel segment below the debris dam

performed in several stages:

- the spring of 2013 - measurements of 22 cross sections of the stream channel and surrounding areas, water level measurements (Figure 7),

- the autumn of 2013 - measurements of six cross sections of the channel within the reservoir area on the upstream side of the debris dam, it was necessary to perform these measurements before the lowering of the crest of the dam in order to be able to control the intensity of headward erosion (causing a headcut);

- the spring of 2014 - measurements of cross sections were repeated in all locations where they were performed before, below and above the dam (Figure 7), measurements of new cross sections were also performed at sites strongly transformed in terms of shape with respect to their status of one year ago.
It may be stated based on the results obtained so far that long segments of the stream channel have been filled with the material released from the reservoir upstream of the dam (Figure 8), and also with the material from the right bank subjected to strong bank erosion (Figures 8 and 9). The following figures depict examples of cross sections, in order to show how the stream channel changed after the high discharge event (Figures 8-11). The magnitude and nature of changes, which occurred at the subsequent cross sections in the researched reach of the channel, are presented in Table 2. The magnitude of change is represented by a difference in minimum elevation. However, a small difference between two given values may be misinterpreted. That is why, additionally, an average thickness of a sediment layer or an average lowering of the stream channel bottom was calculated. A brief description of stream channel processes,

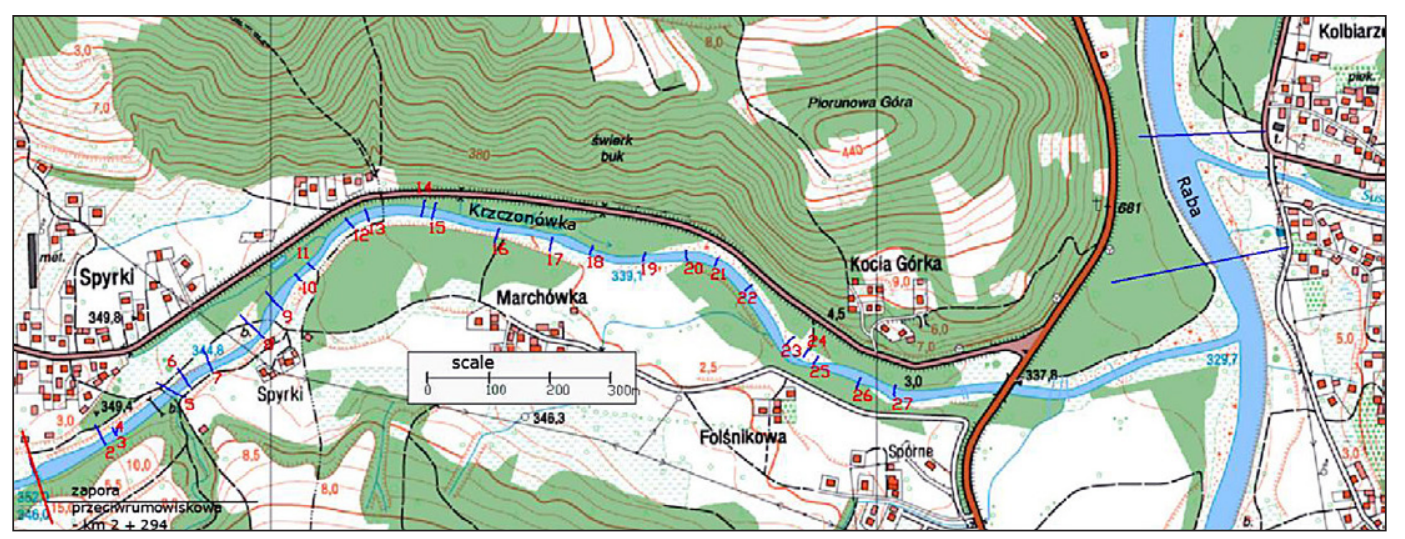

Figure 7. The lower reach of the Krzczonówka River ending at its mouth. Locations of cross sections, where measurements were performed in 2013 and then again in 2014, are marked on the map 


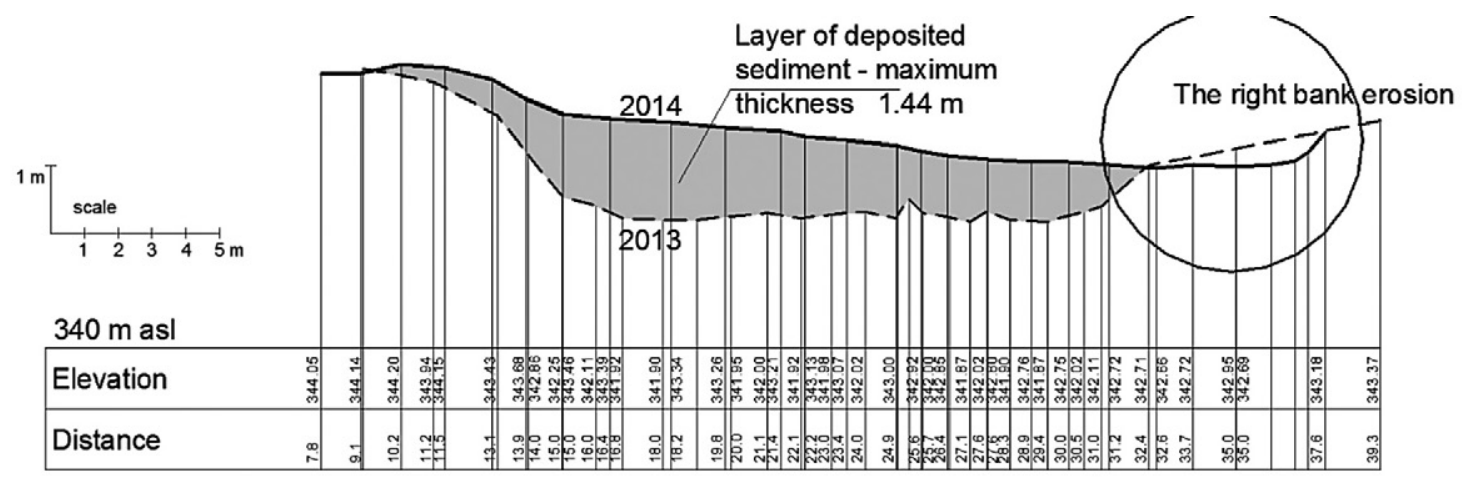

Figure 8. Cross-section number 9 of the Krzczonówka River at RKm $1+0.795$. The right bank erosion site is circled

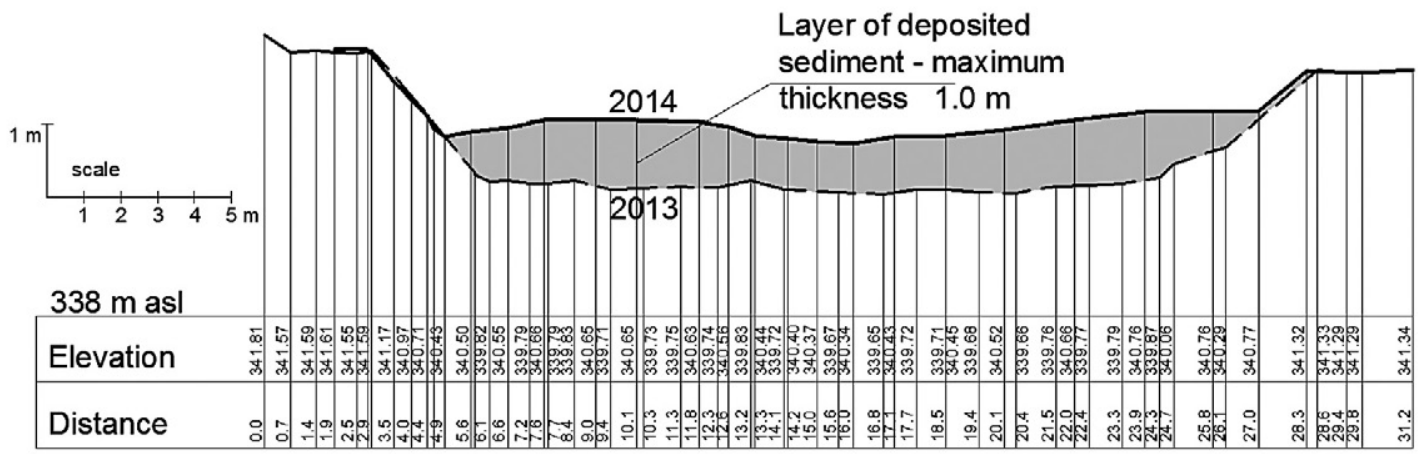

Figure 9. Cross-section number 15 of the Krzczonówka River at RKm $1+0.475$. Shaded areas represent layers of deposited sediment, with specified layer thickness

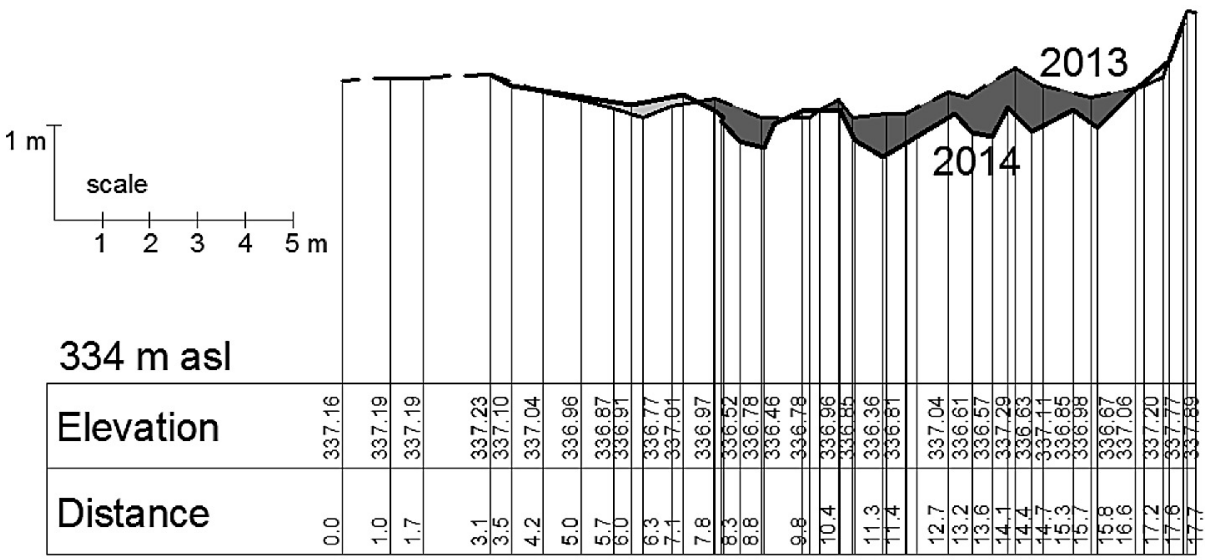

Figure 10. Cross-section number 20 of the Krzczonówka River at RKm $1+0.040$. The black area on the diagram represents the difference in bed level due to erosion

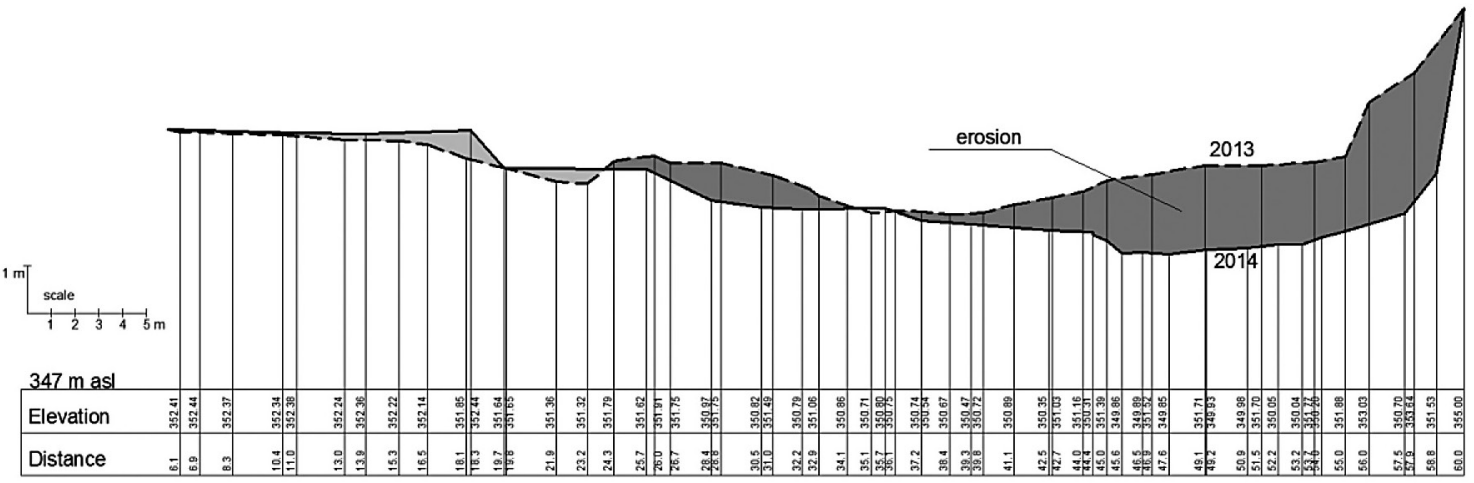

Figure 11. A cross section above the debris dam, here, channel deepening reached a maximum value of about $1.8 \mathrm{~m}$ 
Table 2. Summary of measurement data on the reach of the Krzczonówka River below the debris dam

\begin{tabular}{|c|c|c|c|c|c|}
\hline \multirow[t]{2}{*}{ Cross section } & \multicolumn{2}{|c|}{$\begin{array}{c}\text { Minimum elevation of the } \\
\text { stream bed in } m \text { above } \\
\text { sea level }\end{array}$} & \multirow{2}{*}{$\begin{array}{c}\text { Average } \\
\text { thickness of } \\
\text { sediment layer } \\
\text { / stream bed } \\
\text { lowering [m] }\end{array}$} & \multirow[t]{2}{*}{ Stream channel processes } & \multirow{2}{*}{$\begin{array}{l}\text { Change in the } \\
\text { cross sectional } \\
\text { area of the stream } \\
\text { channel [\%] }\end{array}$} \\
\hline & 2013 & 2014 & & & \\
\hline Cross section 5' & 344.65 & 344.68 & 0.41 & Accumulation in the middle of the channel & -16.12 \\
\hline Cross section 6' & 343.85 & 344.20 & 0.60 & Accumulation in the middle of the channel & -10.08 \\
\hline Cross section 7' & 343.58 & 343.65 & 0.43 & Accumulation at the right bank & -33.57 \\
\hline Cross section 8' & 342.47 & 342.68 & 0.71 & $\begin{array}{l}\text { Accumulation in the central part of the } \\
\text { channel, right bank erosion }\end{array}$ & -23.13 \\
\hline Cross section 9' & 341.87 & 342.66 & 0.91 & $\begin{array}{l}\text { Accumulation in the central part of the } \\
\text { channel, right bank erosion }\end{array}$ & -46.72 \\
\hline Cross section 10' & 341.34 & 341.72 & 0.86 & Accumulation at the right bank & -71.37 \\
\hline Cross section $11^{\prime}$ & 340.88 & 341.51 & 0.89 & Accumulation at the right bank & -73.16 \\
\hline Cross section 12' & 340.68 & 341.17 & 0.47 & $\begin{array}{l}\text { Accumulation in the central part of the } \\
\text { channel }\end{array}$ & -34.76 \\
\hline Cross section 13' & 340.20 & 341.07 & 0.68 & $\begin{array}{l}\text { Accumulation across the whole width of } \\
\text { the channel }\end{array}$ & -39.13 \\
\hline Cross section 14' & 339.77 & 340.46 & 0.58 & $\begin{array}{l}\text { Accumulation across the whole width of } \\
\text { the channel }\end{array}$ & -41.83 \\
\hline Cross section 15' & 339.65 & 340.34 & 0.72 & $\begin{array}{l}\text { Accumulation across the whole width of } \\
\text { the channel }\end{array}$ & -47.93 \\
\hline Cross section $16^{\prime}$ & 339.03 & 339.34 & 0.46 & Accumulation at the left bank & -11.39 \\
\hline Cross section $17^{\prime}$ & 338.11 & 338.07 & 0.55 & $\begin{array}{l}\text { Accumulation at the left bank, right bank } \\
\text { erosion }\end{array}$ & -6.55 \\
\hline Cross section 18' & 337.34 & 337.61 & 0.41 & Accumulation at the left bank & -20.69 \\
\hline Cross section 19' & 336.93 & 336.94 & 0.21 & Minimal accumulation at the left bank & -14.39 \\
\hline Cross section 20' & 336.77 & 336.36 & -0.30 & Downward erosion & +15.16 \\
\hline Cross section $21^{\prime}$ & 335.72 & 335.75 & 0.31 & Minimal accumulation at the right bank & -13.22 \\
\hline Cross section 22' & 335.44 & 335.51 & no data & - & -2.54 \\
\hline Cross section 23' & 334.35 & 334.69 & 0.44 & $\begin{array}{l}\text { Accumulation across the whole width of } \\
\text { the channel }\end{array}$ & -40.42 \\
\hline Cross section 24' & 333.97 & 334.31 & 0.48 & Accumulation at the right bank & -19.64 \\
\hline Cross section 26' & 333.78 & 333.86 & 0.29 & $\begin{array}{l}\text { Accumulation across the whole width of } \\
\text { the channel }\end{array}$ & -21.63 \\
\hline Cross section $27^{\prime}$ & 332.65 & 332.93 & 0.15 & - & -20.62 \\
\hline
\end{tabular}

which occurred at the site of a given cross section, was also provided. Finally, an estimated change in the cross sectional area of the stream channel, was specified. Summarizing the results contained in the table, it may be observed that accumulation is the primary process that occurs over the whole stream segment. The thickness of deposited sediment is in the range from 0.21 to $0.91 \mathrm{~m}$. The layer of deposited sediment is thin at cross sections closest to the dam. The sediment layer gets thicker downstream of the dam and reaches maximum values in the vicinity of cross sections No. 9, 10 and 11 . The amount of sediment transported through these cross sections is increased by additional sediment that originates from the eroding right bank. Farther downstream, accumulation decreases as the stream flows through the next cross sections. Subsequently, a deepening of the stream channel actually occurred at cross section No. 20, although it was rather minor.
The cross sectional area of the stream channel changes in a similar manner. The change is small just downstream of the debris dam, and reaches $33 \%$. The occurring changes reach maximum values at cross sections No. 10 and 11, where the cross sectional area decreased by more than $70 \%$. Farther downstream, the area of the stream channel cross sections decreased and the change ranged from $47 \%$ to the minimum value of $2.54 \%$, which occurred at cross section No. 22.

An analysis of cross sections upstream of the debris dam, which is being lowered, shows that this segment of the channel has also been substantially transformed. Large amounts of sediment, entrained by the high discharge event, caused sudden erosion over a long stretch of the channel. Its effects are visible along a $2 \mathrm{~km}$ long channel segment above the dam. A selected cross section, located in the reservoir part of the dam, is shown in Figure 11. It can be seen that the stream bed 

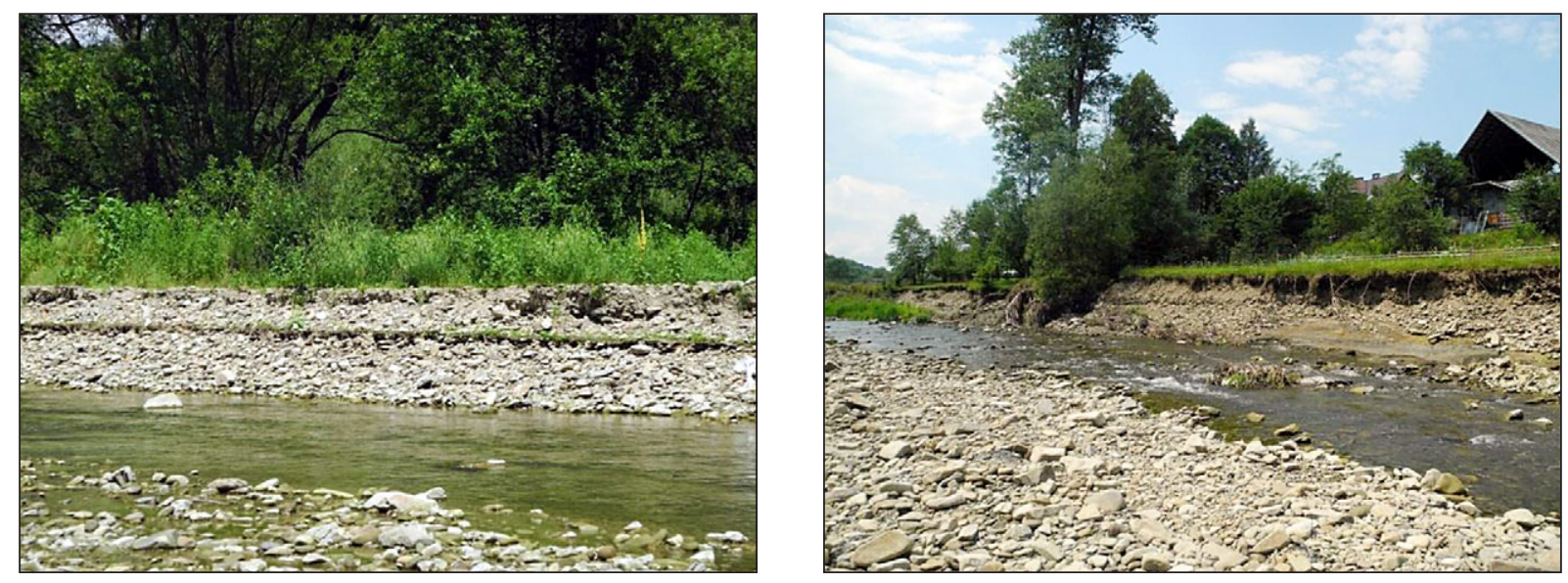

Photo 3. Cutbanks found in the stream segment above the debris dam, which is being lowered

lowered by about 1.8 meters. The cutbanks found in the stream segment upstream of the debris dam are shown on the selected photographs (Photo 3 ).

\section{DISCUSSION}

Rains and flood stages occurred during the period of time when construction was underway to change the structure of the debris dam. This caused an increased entrainment and transport of sediment out of the reservoir part of the debris dam. It also resulted in spectacular changes in the river channel reach upstream and in the river channel reach downstream of the hydraulic structure being modified.

The lowering of the debris dam will have an effect on the biology of the river. However, it will be observable after all planned construction work is finished. Once the river corridor becomes unobstructed, migration of living organisms up the river will be possible. At present, it is only the changes to the river channel that are visible.

The riffles that were constructed were, to some extent, the cause of accumulation in the lower course of the river. The way they were constructed relied on building up the crest of an existing riffle in order to heighten it. These structures helped to reduce the river slope. Consequently, it resulted in a slower sediment transport. Sediment was being trapped in the pools preceding subsequent riffles.

The project assumed that lowering the dam crest will provide a gradual supply of sediment for a long time. Large flood event caused sediment transport from a river reach lying above the debris dam to the reach lying below it. The river reach upstream of debris dam was transformed from ac- cumulation into erosion and riverbed downstream of debris dam was buried with material.

An analysis of cross sections reveals that the crests of the riffles closest to the debris dam were the same height as before or their height actually increased. However, the condition of the riffle structures cannot be inspected due to the amount of sediment that was deposited. It is assumed that the constructed riffle structure worked the way that it was supposed to and it was reinforced by the deposited material. The next flood stages will show whether the riffle and pool system buried by the sediment will be preserved. Since the delivery of material from the river reach lying upstream of debris dam will be significantly reduced, a downcutting of river bed and re-deposition of sediment can be expected.

A field inspection of the riffles constructed in the lower reach of the river, close to the river mouth, produced doubts as to their durability. Accumulation that occurred there was minimal (Table 2). Furthermore, erosion is observed at cross section No. 20 (Figure 10). The very high flow and limited transport of sediment both weakened the most downstream structures. Riffle No. 16 has been entirely washed away. The subsequent phases of washing away of the riffle are shown on the photographs (Photo 4).

The river slope just upstream from a riffle crest is smaller, so the flow velocity is also small, whereas the water flowing over the riffle accelerates. The structure of a riffle remains unchanged at low flows. However, increasingly higher flows cause washing away of ever larger grained sediment. In effect, after a while, only the frame of the structure remains, which is not wedged by smaller supporting structural elements (Photo 4b). Concurrently, a dip in the river bed is created at 
a)

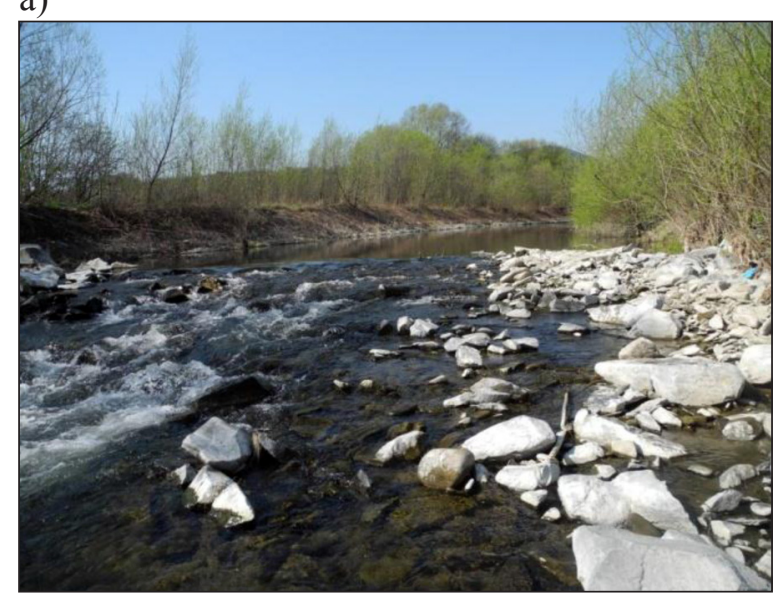

c)

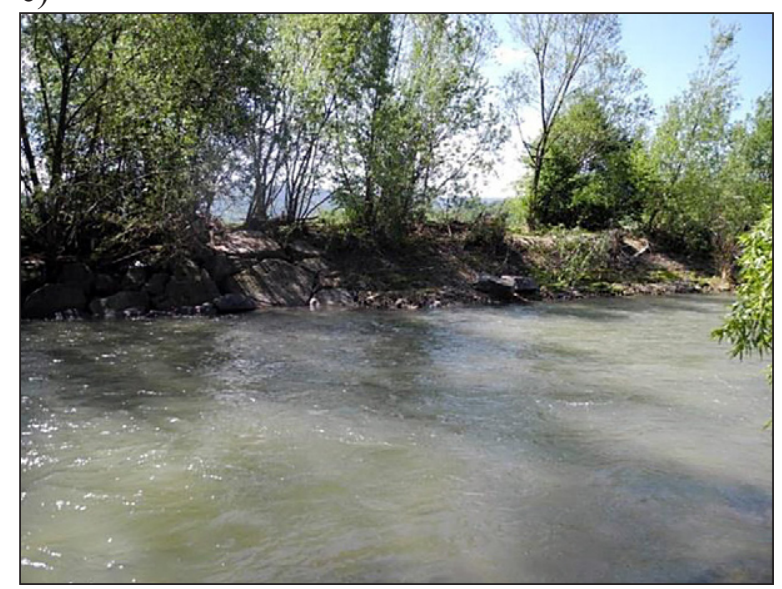

b)

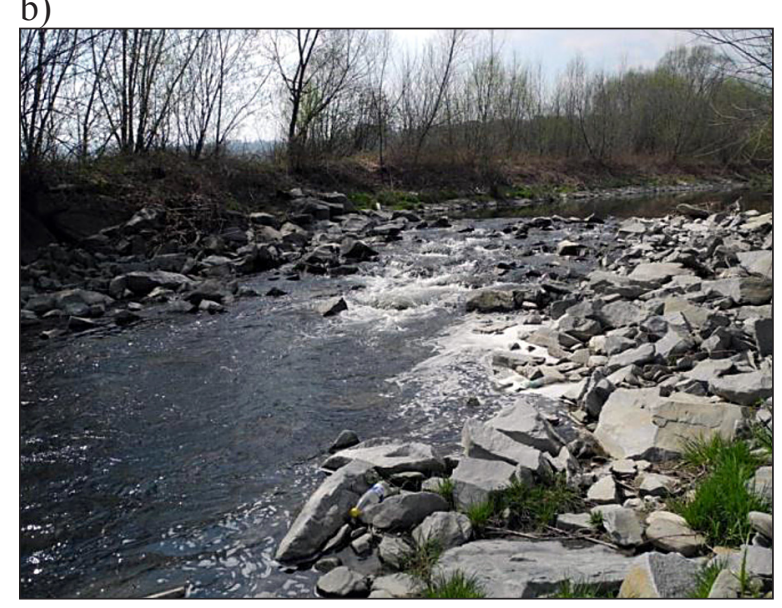

d)

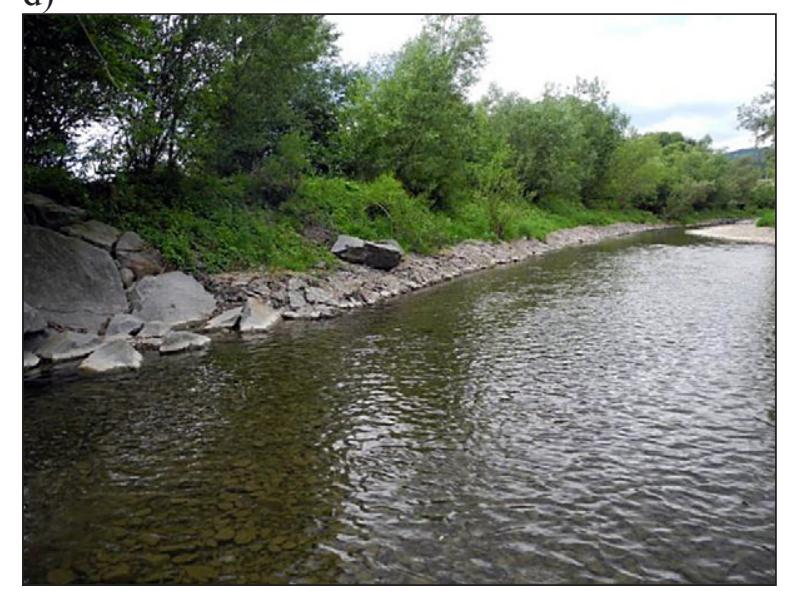

Photo 4. Phases of washing away of riffle number 16: a - spring of 2013, right after it was built; b - April of 2014, loss of small-grained sediment is seen, c - May of 2014, after the maximum flow event, d-June of 2014, no trace of the structure built last year

high flows, just downstream from the riffle. The dip becomes ever larger, and it decreases the energy of the flow. The next stage involves shifting of major structural elements due to the action of flowing water. The structural elements are pushed by the impact of water flow and subsequently "sunk" in the created pool.

Many researchers described their experiences with the use of riffles. Designing a riffle and pool system is a complex process that should be based on engineering, geomorphological, and ecological knowledge [Darby and Sear 2008]. Using that knowledge is an approach that may help to construct structures of increased effectiveness and durability. Methods of protecting riffles from damage due to high water flows were developed and described based on observations of artificial riffle structures that were already constructed. The simplest solution is to reinforce a riffle with stiffeners on its upstream and its downstream end. An example of this kind of riffle is found in another tributary of the Raba River, called
Porębianka [Radecki-Pawlik 2013]. Retaining wall protect the river bed, especially on the downstream end of a riffle, just upstream of the dip in the river bed. Additionally, if retaining wall are firmly and deeply set, they prevent washing out of fine-grained material by the scouring action of flowing water. The retaining wall" "flaw" is their heavy construction, which requires a substantial intervention in the river channel in order to build it. The introduction of these types of hydraulic structures requires preparing appropriate project documentation and local authorities' guidelines concerning water-related issues. According to other papers, this type of approximately natural riffle must be constructed with utmost precision. There are many factors that significantly affect the durability of these structures: their shape, the size and arrangement of stones used to build each structure, the slope of the riffle on its upstream and downstream ends, an adequate protection of the pool below it [Ślizowski and Radecki-Pawlik 1999], and the location of the riffle crest [Kapitz- 
ke 2010, Mooney et al. 2007, Ślizowski 1993, RRC 2002]. It was also concluded in the cases described that a flood stage will always damage the structure of a riffle that was not reinforced. Hence, any loss of material, which occurred due to washing out, must be filled in after a high flow event. Prior observations prove that riffles may become stabilized after a certain period of time and they will not require reconstruction [Torre 2001].

Considering the earlier state of the lower reach of the river, including intense downward erosion, rock outcroppings being exposed, lack of sediment transport from the upstream reach of the channel, the present state may be judged to be a positive effect of the changes that were introduced. However, vast amounts of sediment deposited in the lower reach of the river decrease the carrying capacity of the river near its mouth (Table 2). It should be verified whether or not this situation poses a threat of flooding to adjacent areas. There are also questions about the erosion, which occurred upstream from the debris dam. Cutbanks are there observed and the rock river bed was revealed. Lateral erosion is seen along large sections of the river, yet generally it is not a problem since the valley is relatively wide and not developed. There are, however, places where the river nears buildings and it may become dangerous.

\section{CONCLUSIONS}

The study of the Krzczonówka River, which included monitoring the river channel processes, lead to the following essential observations and conclusions, which may now be stated:

1. The intensity of the processes, which occurred in the river channel reach above and in the river channel reach below the debris dam being modified, was due to two events that coincided in time. The two concurrently occurring events were: the construction work on the debris dam, performed in order to lower it, and the maximum flow caused by heavy rains. Their effects were mutually superimposed.

2. Extreme flows occurred shortly after the construction of artificial rapids when the river not yet had time to develop a new profile of equilibrium. Huge sediment supply from the upper river section (due to reduction of the dam) caused the sudden burial of the channel bed downstream of debris dam. Under conditions of average flows deposition process would extend gradually and lasted many years. Observation of further development of the Krzczonówka River reach, especially after the passage of the next flood, fill be very interesting. Availability of material in the section above the dam is already very limited.

3. What may happen under the conditions that exist in mountain rivers in the Polish Carpathians is that high flows, which may not be carrying sediment from the upper reach of the river, may cause disassembling of riffles that are not reinforced.

4. The lowering of the debris dam may have a negative effect on the developed adjacent areas, both upstream and downstream of the renovated dam. Downward erosion and lateral erosion are the threats that may occur upstream of the dam. However, downstream of the dam, it is the accumulation, which causes a decrease in the carrying capacity of the river channel, that may create a danger of flooding.

5. Location, structure, and construction of riffles should be carefully thought out and designed. It should be a result of collaborative work of hydrologic engineering specialists, geomorphologists and ecologists, in order to create more durable and effective hydraulic structures.

6. Using riffles in eroding and deprived of sediment channels of Carpathian rivers, contributes to the improvement of the morphological state of these channels. Riffles prevent further erosion, and in the case where sediment supply exists (from the upper reach of the river channel, from the banks or from the catchment), they initiate the process of deposition, thus contributing to the restoration of alluvial river channels and to the increasing of biodiversity.

\section{REFERENCES}

1. Bojarski A., Jeleński J., Jelonek M., Litewka T., Wyżga B., Zalewski J. 2005. Zasady dobrej praktyki w utrzymaniu rzek i potoków górskich [GoodPractice manual of sustainable maintenance of mountain streams and river in Southern Poland]. Ministerstwo Środowiska. Departament Zasobów Wodnych [Department of the Environment, Water Resources Office] [in Polish].

2. Darby S., Sear D. (Eds.) 2008. River restoration: managing the uncertainty in restoring physical habitat. John Wiley \& Sons. 
3. DVWK, FAO. 2002. Fish Passes: Design, Dimensions, and Monitoring.

4. Kamykowska M., Kaszowski L., Krzemień K. 1999. River channel mapping instructions. Key to the river description. In: K. Krzemień (ed.), River channels. Pattern, structure, and dynamics. Geographical Works of the Institute of Geography of Jagiellonian University, 104, 9-25.

5. Kapitzke I.R. 2010. Culvert fishway planning and design guidelines. James Cook University, Townsville, Australia.

6. Korpak J., Krzemien K., Radecki-Pawlik A. 2008. Wpływ czynników antropogenicznych na zmiany koryt cieków karpackich. [The Influence of anthropogenic factors on the changes in The Carpathian stream channels] Infrastruktura i Ekologia Terenów Wiejskich, 04 [in Polish].

7. Łapuszek M., Lenar-Matyas A. 2013. Utrzymanie i zagospodarowanie rzek górskich [Maintenance, engineering and management of mountain rivers]. Wyd. Politechnika Krakowska, Kraków [in Polish].

8. Ministerstwo Środowiska [Dept. of the Environment] 2009. Natura 2000 a gospodarka wodna [Nature 2000 and water management] [in Polish].

9. Mooney D.M., Holmquist-Johnson C.L., Broderick S. 2007. Rock ramp design guidelines. US Department of the Interior, Bureau of Reclamation, Technical Service Center Denver, Colorado.

10. Nienhuis P.H., Leuven R.S.E.W. 2001. River restoration and flood protection: controversy or synergism? Hydrobiology, 444, 1, 85-99.

11. Radecki-Pawlik A. 2013. On using artificial rapid hydraulic structures (rhs) within mountain stream channels - some exploitation and hydraulic problems. In: Rowiński P. (Ed.) Experimental and
Computational Solutions of Hydraulic Problems. Series: GeoPlanet: Earth and Planetary Sciences, Monograph, Springer, pp. 425, 101-115.

12. Rosgen D.L. 2006. The Cross-vane, W-weir and J-hook Vane Structures (Updated 2006). Their description, design and application for stream stabilization and river restoration, Pagosa Springs, CO.

13. Ślizowski R. 1993. Bystrza o zwiększonej szorstkości jako element zabudowy potoków górskich, Rozpr. hab. [A post-doctoral dissertation] nr 181, Zesz. Nauk. AR w Krakowie (in Polish).

14. Ślizowski R., Radecki-Pawlik A. 1999. Rozmycie nieumocnionego dna poniżej bystrzy o zwiększonej szorstkości. Zesz. Nauk. AR w Krakowie, vol. 19, 115-123 (in Polish).

15. Torre A. 2001. Stream stabilisation, water and rivers commission. Report RR, 10.

16. Wyżga B., Zawiejska J., Radecki-Pawlik A., Hajdukiewicz H. 2012. Environmental change, hydromorphological reference conditions and the restoration of Polish Carpathian rivers. Earth Surface Processes and Landforms, John Wiley and Sons 37, 1213-1226.

17. Zając T., Zając K. 2006. Ochrona i gospodarowanie w obszarach systemu Natura 2000 w dolinach rzecznych. [Protection and management in Natura 2000 areas located in river valleys] Infrastruktura i Ekologia Terenów Wiejskich, 4(1) [in Polish].

18. Ab Ovo 2011. Tarliska Górnej Raby. Opis techniczny [A technical description] TGR-O-R-002-02 (Available on http://www.tarliskagornejraby.pl/ download.php?view.11)

19. River Restoration Centre 2002. Manual of river restoration techniques. Silsoe, U.K. (Available at http://www.therrc.co.uk/manual.php). 